\title{
Faktor-Faktor yang Berhubungan dengan Perilaku Tidak Aman pada Karyawan Departemen Produksi di PT X Jakarta
}

\author{
Laras Dewi Untari, Devi Angeliana Kusumaningtiar, \\ Putri Handayan, Fierdania Yusvita \\ Program Studi Kesehatan Masyarakat, Fakultas Ilmu-Ilmu Kesehatan, \\ Universitas Esa Unggul
}

\begin{abstract}
Abstrak
Latar Belakang : Kasus perilaku tidak aman pada divisi produksi PT X Jakarta menyebabkan kecelakaan kerja dengan total 19 kasus dari data tahun 2015-2020. Tujuan dilakukannya penelitian ini adalah untuk mengethui bebrapa faktor penyebab terkait dengan perilaku tidak aman pada karyawan departemen produksi di PT X Jakarta tahun 2021.

Metode : Desain penelitian yang digunakan adalah sectional cross. Populasi penelitian ini adalah karyawan pada divisi produksi PT X Jakarta. Sampel pada penelitian ini berjumlah 45 responden. Instrumen yang digunakan adalah kuesioner terdiri dari 6 variabel diantaranya adalah perilaku tidak aman, umur, pendidikan, pengetahuan, pelatihan $K 3$ dan pengawasan. pengujian chi square dilakukan untuk melakukan analisis data secara univariat dan bivariat.

Hasil : Hasil dari penelitian diketahui bahwa ada hubungan yang kuat antara pendidikan (Pv=0.02), pelatihan $(P v=0.04)$ dan pengawasan $(P v=0.03)$ dengan kasus perilaku tidak aman, sedangkan tidak terdapat hubungan antara umur $(P v=0.71)$ dan pengetahuan $(P v=0.92)$ dengan kejadian perilaku tidak aman. Kesimpulan : Perusahaan harus dapat mengoptimalkan segala bentuk program K3 yang ada dengan mengatur jadwal pelatihan K3 yanglebih baik lagi dan melakukan peningkatan pengawasan kepada seluruh karyawan terkait kecelakaan kerja yang disebabkan oleh perilaku tidak aman serta memberikan pembinaan yang lebih mendalam lagi terkait pengetahuan perilaku tidak aman.
\end{abstract}

Kata kunci : Perilaku Tidak Aman, Pelatihan, Pengawasan

\section{The Factors Associated With Unsafe Behavior in The Production Department Employees at PT X Jakarta}

\begin{abstract}
Background : Any case of unsafe behavior in production department PT X Jakarta caused work accidents with a total of 19 cases from 2015 - 2020 data. The purposes of this experiment are to determine factors associated with unsafe behavior in production division employees at PT X Jakarta in 2021.

Method : Research design used was sectional cross. Population of this study were employees in the production division of PT X Jakarta. 45 respondents are amounted for Sample in this experiment. Instrument used was a questionnaire consisting of 6 variables, namely unsafe behavior, age, education, knowledge, K3 training and supervision. Chi square test are use to analyzing data with univariat and bivariat method.

Result : The results showed that there was a significant correlation between education $(P v=0.02)$ training $(P v=0.04)$ and supervision $(P v=0.03)$ with case of unsafe behavior, while there was no relationship between age $(P v=0.71)$ and knowledge $(P v=0.92)$ with the case of unsafe behavior.

Conclusion : Companies must be able to optimize all forms of existing K3 programs by arranging a better K3 training schedule and increasing supervision of all employees regarding unsafe behavior that can lead to work accidents and providing deeper guidance regarding knowledge of unsafe behavior.
\end{abstract}

Keywords : Unsafe Behavior, Training, Supervision

Korespondensi: Devi Angeliana Kusumaningtiar Email : deviangeliana@esaunggul.ac.id 


\section{PENDAHULUAN}

Keselamatan kerja dapat diartikan sebagai perlindungan atas keamanan kerja yang dialami pekerja baik secara mental maupun fisik yang terjadi di lingkungan pekerjaan. ${ }^{1} \quad$ Keselamatan kerja juga merupakan indikator yang menunjukkan kondisi yang aman atau selamat dari penderitaan, kerusakan atau kerugian di tempat kerja. Perilaku tidak aman yang dilakukan oleh pekerja merupakan salah satu faktor resiko yang berpengaruh terhadap keselamatan kerja di industri.

Sebagian besar kecelakaan terhadap pekerja kemungkinan terjadi akibat adanya tindakan perilaku tidak aman yang dilakukan oleh seseorang atau beberapa orang karyawan. Perilaku tidak aman sebagai salah satu faktor penyumbang terbesar terjadinya kecelakaan kerja tidak hanya dilakukan oleh pekerja yang terlibat secara langsung tetapi juga dapat dilakukan akibat kesalahan yang dilakukan secara tidak langsung oleh organisasi atau pihak manajemen industri. Hal ini dapat disimpulkan hampir 85\% kecelakaan terjadi karena perilaku tidak aman (unsafe behavior) dari pekerja itu sendiri. $^{2}$

Dikutip dari data International Labour Organization (ILO) tercatat bahwa terjadi sekurang-kurangnya 6.000 kecelakaan kerja fatal di dunia perharinya. Di Indonesia sendiri, setiap harinya tercatat sebanyak 100 ribu pekerja buruh terlibat kasus kecelakaan kerja yang 30\% diantaranya merupakan pekerja pada sektor konstruksi akibat adanya perilaku tidak aman. ${ }^{3}$

Dari tahun 2017 - 2019, BPJSTK Indonesia melayani rata-rata 104 ribu kasus kecelakaan kerja per tahunnya dari kasus ringan sampai dengan kasus - kasus yang berdampak fatal. Tidak sedikit pula kasus kecelakaan kerja yang terjadi dan tidak dilaporkan oleh perusahaan-perusahaan yang tidak mengikuti program tersebut. Hal ini terjadi karena adanya perilaku tidak aman yang menyebabkan terjadinya kecelakaan kerja. ${ }^{4}$

Dampak terburuk yang ditimbulkan dari perilaku tidak aman di perusahaan adalah terjadinya kecelakaan pada pekerja. Terjadinya kecelakaan kerja tersebut menimbulkan banyak kerugian bukan hanya untuk pekerja, tetapi juga untuk organisasi/perusahaan. Kerugian yang diakibatkan dapat berupa kerugian materiil dan yang paling fatal dapat menyebabkan korban jiwa, absensi karyawan yang tidak masuk kerja karena cidera, klaim perawatan karyawan di rumah sakit karena kecelakaan kerja, kerugian karena kerusakan peralatan kerja / properti perusahaan yang memerlukan perbaikan sehingga alat sementara tidak bisa digunakan. Kemudian nantinya akan berpengaruh pada produktifitas perusahaan dan keuntungan perusahaan menurun. ${ }^{5}$

\section{METODE}

Bentuk penelitian ini merupakan penelitian kuantitatif dengan pendekatan cross sectional. Penelitian dilaksankan di PT X Jakarta pada bulan JanuariFebruari 2021. Populasi penelitian ini melibatkan sebanyak 45 orang karyawan pada divisi produksi PT X Jakarta. Pengambilan sampel dilakukan menggunakan metode total sampling.

Instrumen pengumpulan data pada penelitian ini menggunakan kuesioner yang terdiri dari 6 variabel yaitu variabel dependen perilaku tidak aman yang terdiri dari 13 pertanyaan dan variabel indenpenden yaitu umur, pendidikan, pengetahuan terdiri dari 10 pertanyaan, pelatihan terdiri dari 9 pernyataan serta pengawasan terdiri dari 9 pernyataan. Teknik analisis data menggunakan analisis univariat dan bivariat. Analisis univariat dilakukan dengan cara deskriptif menggunakan tabel distribusi frekuensi. Analisis bivariat secara analitik untuk melihat ada atau tidaknya hubungan antara dua variabel dengan uji chi square menggunakan nilai CI 95\%.

\section{HASIL}

Analisi penelitiana ini menggunakan analisis univariat dan bivariat, analisa univariat dilihat dengan menggambarkan distribusi frekuensi untuk variabel independen yaitu perilaku tidak umur, pendidikan, pengetahuan, pelatihan dan pengawasan. Variabel-variabel tersebut dikelompokkan berdasarkan nilai ambang batasnya masing-masing variabel yang telah ditentukan melalui definisi operasional. 


\section{Analisa Univariat}

Dibawah ini merupakan hasil analisa univariat dari masing-masing variabel penelitian, baik independen maupun dependen pada karyawan produksi PT X Jakarta Tahun 2021.

\begin{tabular}{|c|c|c|}
\hline Variabel & Jumlah (n) & $\begin{array}{c}\text { Presentase } \\
(\%)\end{array}$ \\
\hline \multicolumn{3}{|c|}{ Perilaku tidak aman } \\
\hline Tidak Aman & 25 & 55,6 \\
\hline Aman & 20 & 44,4 \\
\hline \multicolumn{3}{|l|}{ Umur } \\
\hline Tua & 9 & 20 \\
\hline Muda & 36 & 80 \\
\hline \multicolumn{3}{|l|}{ Pendidikan } \\
\hline Dasar & 37 & 82,2 \\
\hline Tinggi & 8 & 17,8 \\
\hline \multicolumn{3}{|l|}{ Pengetahuan } \\
\hline Rendah & 15 & 33,3 \\
\hline Tinggi & 30 & 66,7 \\
\hline \multicolumn{3}{|l|}{ Pelatihan } \\
\hline Tidak Pernah & 20 & 44,4 \\
\hline Pernah & 25 & 55,6 \\
\hline \multicolumn{3}{|l|}{ Pengawasan } \\
\hline Tidak Baik & 18 & 40 \\
\hline Baik & 27 & 60 \\
\hline
\end{tabular}

Berdasarkan Tabel 1, proporsi tertinggi perilaku karyawan produksi adalah perilaku aman pada keryawan sebanyak 25 karyawan (55,6\%), pendidikan dasar (SD/SMP \& SMA/SMK) sebanyak 37 karyawan $(82,2 \%)$, pengetahuan perilaku tidak aman yang tinggi sebanyak 30 karyawan $(66,7 \%)$, pernah mengikuti pelatihan K3 sebanyak 25 karyawan $(55,6 \%)$, adanya pengawasan yang baik terhadap 27 karyawan $(60,0 \%)$.

\section{Analisa Bivariat}

Di bawah ini merupakan hasil analisis bivariat yang diuji menggunakan chi square untuk mengetahui ada atau tidaknya keterkaitan antara variabel independen dan variabel dependen karyawan produksi PT X Jakarta Tahun 2021.
Tabel 2. Uji statistik faktor-faktor yabg berhubungan dengan perilaku tidak aman Karyawan Departemen Produksi PT X Jakarta

\begin{tabular}{|c|c|c|c|c|}
\hline \multirow{2}{*}{ Kategori } & \multicolumn{2}{|c|}{$\begin{array}{c}\text { Perilaku Tidak } \\
\text { Aman }\end{array}$} & \multirow{2}{*}{ Total } & \multirow{2}{*}{$\begin{array}{c}p- \\
\text { value }\end{array}$} \\
\hline & $\begin{array}{l}\text { Tidak } \\
\text { Aman }\end{array}$ & Aman & & \\
\hline \multicolumn{5}{|l|}{ Umur } \\
\hline Tua & $\begin{array}{c}6 \\
(66.7 \%)\end{array}$ & $\begin{array}{c}3 \\
(33.3 \%)\end{array}$ & $\begin{array}{c}9 \\
(100 \%)\end{array}$ & \multirow{2}{*}{0.71} \\
\hline Muda & $\begin{array}{c}19 \\
(52.8 \%)\end{array}$ & $\begin{array}{c}17 \\
(47.2 \%)\end{array}$ & $\begin{array}{c}36 \\
(100 \%)\end{array}$ & \\
\hline \multicolumn{5}{|l|}{ Pendidikan } \\
\hline Dasar & $\begin{array}{c}24 \\
(64.9 \%)\end{array}$ & $\begin{array}{c}13 \\
(35.1 \%)\end{array}$ & $\begin{array}{c}37 \\
(100 \%)\end{array}$ & \multirow{2}{*}{0.02} \\
\hline Tinggi & $\begin{array}{c}1 \\
(12.5 \%)\end{array}$ & $\begin{array}{c}7 \\
(87.5 \%)\end{array}$ & $\begin{array}{c}8 \\
(100 \%)\end{array}$ & \\
\hline \multicolumn{5}{|l|}{ Pengetahuan } \\
\hline Rendah & $\begin{array}{c}9 \\
(60 \%)\end{array}$ & $\begin{array}{c}6 \\
(40 \%)\end{array}$ & $\begin{array}{c}15 \\
(100 \%)\end{array}$ & \multirow{2}{*}{0.92} \\
\hline Tinggi & $\begin{array}{c}16 \\
(53.3 \%)\end{array}$ & $\begin{array}{c}14 \\
(46.7 \%)\end{array}$ & $\begin{array}{c}30 \\
(100 \%)\end{array}$ & \\
\hline \multicolumn{5}{|l|}{ Pelatihan } \\
\hline $\begin{array}{l}\text { Tidak } \\
\text { Pernah }\end{array}$ & $\begin{array}{c}15 \\
(75 \%)\end{array}$ & $\begin{array}{c}5 \\
(25 \%)\end{array}$ & $\begin{array}{c}20 \\
(100 \%)\end{array}$ & \multirow{2}{*}{0.04} \\
\hline Pernah & $\begin{array}{c}10 \\
(40 \%)\end{array}$ & $\begin{array}{c}15 \\
(60 \%)\end{array}$ & $\begin{array}{c}25 \\
(100 \%)\end{array}$ & \\
\hline \multicolumn{5}{|l|}{ Pengawasan } \\
\hline Tidak Baik & $\begin{array}{c}14 \\
(77.8 \%)\end{array}$ & $\begin{array}{c}4 \\
(22.2 \%)\end{array}$ & $\begin{array}{c}18 \\
(100 \%)\end{array}$ & \multirow{2}{*}{0.03} \\
\hline Baik & $\begin{array}{c}16 \\
(59.3 \%)\end{array}$ & $\begin{array}{c}11 \\
(40.7 \%)\end{array}$ & $\begin{array}{c}27 \\
(100 \%)\end{array}$ & \\
\hline
\end{tabular}

Berdasarkan hasil uji statistik menggunakan uji chi square dengan CI 95\% diatas terlihat bahwa ada hubungan yang kentara antara variabel pendidikan $(P$ value $=0,02)$, pelatihan $(P$ value $=0,04)$ dan pengawasan $(P$ value $=0,03)$ terhadap perilaku tidak aman pada karyawan di departemen produksi PT X Jakarta. Sedangkan variabel umur $(P$ value $=0,71)$ dan pengetahuan $(P$ value $=0,92)$ tidak berhubungan terhadap perilaku tidak aman pada karyawan produksi di PT X Jakarta. 


\section{PEMBAHASAN}

Gambaran Perilaku Tidak Aman Pada Karyawan Departemen Produksi PT X Jakarta.

Berdasarkan hasil analisis univariat proporsi tertinggi perilaku tidak aman pada pekerja adalah pekerja dengan perilaku tidak aman yaitu sejumlah 25 karyawan $(55,6 \%)$. Sedang pekerja dengan perilaku aman sebesar 20 karyawan $(44,4 \%)$. Penelitian ini sejalan dengan hasil penelitian yang dilakukan oleh Sudrajat mengemukakan bahwa responden beresiko perilaku tidak aman sebanyak 74 karyawan $(93,7 \%)$ dalam penelitian ini perilaku tidak aman lebih banyak dibandingkan dengan perilaku aman ${ }^{6}$.

Berdasarkan hasil penelitian melalui kuesioner, diketahui perilaku tidak aman yang paling banyak dilakukan oleh karyawan di departemen produksi adalah tidak menggunakan kacamata pelindung (safety glases) sebanyak 31 karyawan (68,9\%). Menurut hasil pengamatan, hal ini terjadi dikarenakan kurangnya teguran dari pihak pengawas (supervisor) terkait pekerja yang tidak menggunakan kacamata pelindung, Sehingga para pekerja menganggap bahwa kacamata pelindung bukanlah APD yang wajib dikenakan. Sebaiknya pihak pengawas lebih tegas lagi dengan hal tersebut, karena proses kerja di departemen produksi setiap tahapannya berhubungan dengan zat kimia yang berbahaya.

Selanjutnya adalah perilaku tidak aman yang dilakukan oleh karyawan di departemen produksi adalah tidak menggunakan safety shoes dengan benar sebanyak 25 karyawan $(55,6 \%)$, naik turun tangga pada alat produksi dengan tidak berpegangan pada handrail sebanyak 25 karyawan $(55,6 \%)$, menggunakan handphone saat bekerja sebanyak 25 karyawan $(55,6 \%)$, mengangkat beban tidak sesuai prosedur yang aman sebanyak 23 karyawan $(51,1 \%)$, pelanggaran terhadap safety sign sebanyak 21 karyawan $(46,7 \%)$. Berdasarkan hasil pengamatan, hal ini terjadi dikarenakan kurangnya tingkat disiplin karyawan produksi terhadap tanda keseamatan (safety sign) yang telah terpasang di area produksi. Diketahui safety sign telah ditempatkan di area yang mudah terlihat dan gambar terlihat dengan sangat jelas.

Selanjutnya adalah perilaku tidak aman terkait penggunaaan wearpack putih ke area diluar ruang produksi sebanyak 20 karyawan (44,4\%), bekerja melebihi kapasitas mesin yang digunakan sebanyak 18 karyawan (40\%), memperbaiki mesin dalam keadaan menyala sebanyak 18 karyawan (40\%), menggunakan aksesoris saat bekerja sebanyak 18 karyawan (40\%), tidak menjalankan 5R dalam proses bekerja sebanyak 17 karyawan $(37,8 \%)$, tidak menggunakan masker pelindung gas respirator saat bekerja dengan bahan kimia yang berbahaya sebanyak 13 karyawan $(28,9 \%)$, tidak menggunakan sarung tangan saat bekerja sebanyak 9 karyawan $(20 \%)$. Diketahui hampir seluruh perilaku tidak aman yang dilakukan oleh karyawan produksi adalah karena rendahnya kesadaran akan keselamatan kerja. Sebaiknya perusahaan mengoptimalkan program K3 terkait inpeksi dadakan yang biasanya dilakukan setiap bulan untuk karyawan yang masih kurang baik dilakukan setiap minggu untuk meningkatkan tingkat disiplin pekerja. Dalam pelaksanaan program pelatihan K3 perusahaan perlu mengadakan pre test dan post test untuk memastikan bahwa materi pelatihan telah dipahami oleh karyawan.

\section{Hubungan Antara Umur Dengan Perilaku Tidak Aman Pada Karyawan Departemen Produksi di PT X Jakarta}

Umur dapat menunjukkan tingkat kematangan seseorang dalam bekerja, semakin bertambah umur maka seseorang semakin matang dalam bertindak. Hal ini dilihat dengan terbentuknya pola pikir rasional seiring dengan bertambahnya umur seseorang, Selain itu seseorang dengan kematangan umur juga lebih menunjukkan adanya kematangan intelektual dan psikologis sehingga lebih bisa mengontrol emosi dan sifat lainnya. Sedangkan pekerja pada usia muda memiliki kecenderungan emosi yang tidak stabil, dan lebih meremehkan terhadap bahaya dan risiko yang dapat terjadi pada lingkungan kerja sehingga membuat pekerja menjadi kurang berhatihati dalam bekerja. ${ }^{7}$

Berdasarkan analisis univariat distribusi frekuensi umur karyawan di PT X Jakarta Tahun 2021 umur kategori muda $80 \%$ lebih tinggi dibandingkan umur kategori tua yaitu $20 \%$. Berdasarkan analisis bivariat dengan pengujian chi square 
didapatkan nilai Pvalue $=0,71$ maka tidak ada hubungan antara umur dengan perilaku tidak aman pada karyawan divisi produksi di PT X Jakarta.

Hasil analisis penelitian ini sesuai dengan hasil penelitian yang menyimpulkan bahwa tidak ada hubungan umur dengan kasus perilaku tidak $\operatorname{aman}^{8}$ dan penelitian yang menyimpulkan bahwa tidak ada hubungan yang signifikan antara perilaku tidak aman dengan usia pekerja. ${ }^{9}$ Dan tidak sejalan dengan penelitian yang menyimpulkan bahwa umur memiliki hubungan yang kuat dengan beberapa kasus kecelakaan kerja. ${ }^{10}$

Hasil wawancara dengan pihak HRD terkait pengadaan SDM (Sumber Daya Manusia) di departemen produksi, menjelaskan bahwa frekuensi jumlah karyawan berumur muda lebih tinggi dibandingkan dengan karyawan berumur tua dikarekan berkurangnya karyawan lama yang beberapa telah pensiun, sehingga di dominasi oleh karyawan baru yang rata-rata berumur 29 tahun. Selain itu dikarenakan adanya masa kontrak kerja antara 6 bulan hingga 1 tahun apabila pekerja tidak kompeten dalam masa percobaan maka akan diakhiri masa kerjanya sehingga perusahaan melakukan rekrutment kembali.

Hasil dari penelitian ini didapatkan bahwa pekerja dengan kategori umur muda cenderung melakukan perilaku tidak aman sebesar $52,8 \%$ dan karyawan dengan umur yang lebih tua cenderung melakukan perilaku tidak aman sebesar $66,7 \%$. Dari sini bisa disimpulkan bahwa karyawan yang berumur tua lebih percaya diri sehingga menganggap seluruh pekerjaan telah dapat dikuasai tanpa memperhatikan SOP (Standar Operasional Prosedur) keselamatan kerja. Sedangkan karyawan berumur muda memiliki pengalaman kerja yang belum cukup luas sehingga lebih menganggap keselamatan kerja bukanlah hal yang sangat penting.

\section{Hubungan Antara Pendidikan Dengan Perilaku Tidak Aman Pada Karyawan Departemen Produksi di PT X Jakarta.}

Pendidikan merupakan salah satu dari sekian banyak parameter karakteristik yang dimiliki seseorang dan menjadi dasar perilaku bagi pekerja. Pendidikan menjadi hal yang penting untuk diperhatikan guna meningkatnya kesadaran dan pentingnya kesehatan dan keselamatan kerja. Tingkat pendidikan dari setiap pekerja menunjukan seberapa baik pengetahuan yang mepengaruhi perilaku dalam bekerja.

Dari hasil analisis univariat pendidikan karyawan divisi produksi di PT $\mathrm{X}$ Jakarta didominasi oleh karyawan yang berpendidikan dasar yaitu SMA/SMK sebesar $82,2 \%$ dan pendidikan tinggi sebesar $17,8 \%$. Dilihat dari analisis bivariat diperoleh nilai $\mathrm{P}$ value $=0,02$ maka dapat disimpulkan ada hubungan yang signifikan antara pendidikan dengan perilaku tidak aman pada karyawan divisi produksi di PT X Jakarta Tahun 2021. Hasil penelitian ini tidak sesuai dengan penelitian Saragih et al yang menyimpulkan bahwa tidak ada hubungan antara pendidikan pekerja dengan perilaku tidak aman pekerja. ${ }^{3}$

Berdasarkan hasil wawancara dengan departemen HRD sebagai departemen pengadaan SDM (Suber Daya Manusia) memang memberikan syarat minimal berpendidikan SMA/SMK untuk unit prroduksi selain supervisor dan manager. Sehingga rata-rata tingkat pendidikan karyawan di departemen produksi yaitu SMA/SMK.

Dari hasil penelitian diperoleh hubungan pendidikan dengan kasus perilaku tidak aman di divisi produksi PT X Jakarta memang sangat terlihat jelas. Karyawan dengan pendidikan dasar lebih cenderung berperilaku tidak aman yaitu sebanyak $64,9 \%$ kasus dibandingkan dengan karyawan berpendidikan tinggi sebesar $12,5 \%$. Berdasarkan hasil kuesioner perilaku tidak aman yang dilakukan oleh karyawan berpendidikan dasar (SMA/SMK) seperti tidak menggunakan APD dengan lengkap dan benar, memperbaiki mesin dengan kondisi menyala, bekerja melebihi kapasitas mesin yang digunakan, menggunakan handphone secara diam-diam, mengangkat beban dengan posisi yang tidak ergonomis, menggunakn wearpack putih diluar area produksi, safety sign dilanggar, menggunakan aksesoris saat bekerja hingga tidak berpengangan pada handrill saat naik turun tangga pada alat produksi. Sedangkan perilaku tidak aman yang dilanggar oleh karyawan berpendidikan tinggi (D3/S1) sangat sedikit diantara perilaku tidak aman terkait penggunaan handphone saat bekerja. 
Pekerjaan di departemen produksi merupakan jenis pekerjaan yang membutuhkan suatu keterampilan serta pemahaman disetiap prosesnya termasuk bahaya dan risiko yang ditimbulkan saat bekerja. Pekerja dengan pendidikan SMA/SMK yang ada di departemen produksi PT X Jakarta tidak seluruhnya berasal dari industri farmasi sehingga perlu pendalaman materi yang lebih lagi untuk dapat memiliki kesadaran akan bahaya dan risiko dari setiap proses produksi, seperti dengan pemberian materi MSDS dan kegiatan pelatihan terkait K3. Sedangkan karyawan yang berpendidikan tinggi D3/S1 mereka telah memiliki kesadaran yang sangat baik terkait bahaya dan risiko yang ada dalam proses produksi sehingga hanya sedikit karyawan yang berpendidikan tinggi berperilaku tidak aman. Oleh sebab itu, pendidikan merupakan salah satu faktor yang memiliki hubungan yang signifikan dengan perilaku tidak aman pekerja.

\section{Hubungan Antara Pengetahuan Dengan Perilaku Tidak Aman Pada Karyawan Departemen Produksi di PT X Jakarta.}

Pengetahuan yang berkaitan dengan perilaku tidak aman salah satunya adalah pengetahuan dampak dan resiko ketika tidak bekerja secara aman. Pengetahuan dari setiap pekerja terkait dengan keselamatan kerja yang disebabkan oleh perilaku tidak aman dapat dipresentasikan dengan melakukan kuesioner penelitian yang berisi pertanyaan- pertanyaan terkait dengan teoriteori yang ingin diukur dari subjek penelitian.

Berdasarkan hasil analisis univariat karyawan di departemen produksi memiliki pengetahuan tinggi lebih besar yaitu $66,7 \%$ dibandingkan karyawan dengan pegetahuan rendah yaitu 33,3\%. Dilihat dari hasil analisis bivariat menggunakan uji chi square didapat nilai $\mathrm{P}$ value $=0,92$ maka disimpulkan bahwa tidak ada korelasi antara pengetahuan dengan perilaku tidak aman yang terjadi pada divisi Produksi di PT X Jakarta Tahun 2021.

Kesimpulan dari penelitian ini sesuai dengan penelitian Pangestu \& Kusumaningtiar yang menyimpukan bahwa tidak ada hubungan antara pegetahuan dengan perilaku aman pekerja di PT Total Bangun Persada Tahun 201911 dan penelitian Pratama yang menyatakan bahwa tidak terjadi hubungan yang signifikan anatara pengetahuan dengan perilaku tidak aman karyawan ${ }^{8}$.

Berdasarkan hasil penelitian melalui kuesioner sebagian besar karyawan di departemen produksi PT X Jakarta memiliki tingkat pengetahuan tinggi terkait bentuk dan dampak dari perilaku tidak aman yang dilakukan serta tujuan dari adanya identifikasi bahaya serta diadakannya pelatihan K3. Namun dari hasil kuesioner peneliti diketahui masih banyak pekerja yang kurang memahami definisi perilaku tidak amaan secara tepat serta program untuk mengurangi perilaku tidak aman di departemen produksi.

Berdasarkan hasil uji chi square dapat diketahui tingkat pengetahuan rendah berperilaku tidak aman sebesar $60,0 \%$ dan pengetahuan tinggi berperilaku tidak aman sebesar 53,3\%. Berdasarkan hasil kuesioner penelitian hampir seluruh pekerja telah menjawab dengan tepat pernyataan yang diajukan dalam kuesioner. Diketahui skor dengan jawaban benar tertinggi terdapat dalam pertanyaan mengenai pemahaman terkait penerapan $5 \mathrm{R}$ dalam bekerja, serta beberapa pertanyaan lainnya yang dijawab dengan baik oleh responden seperti pengetahuan mengenai manfaat adanya pelatihan K3, pemahaman penggunaan APD yang tepat, pengendalian kecelakaan kerja, cara angkat- angkut beban serta tujuan identifikasi sumber bahaya. Pengetahuan yang tinggi dari setiap pekerja tidak begitu berpengaruh terhadap perilaku tidak aman dari pekerja itu sendiri, diketahui masih banyak pekerja yang berperilaku tidak aman walaupun telah mengetahu bahaya dan risikonya seperti masih banyak pekerja yang mengangkut beban dengan posisi yang tidak ergonomis, tidak menggunakan APD secara lengkap.

\section{Hubungan Antara Pelatihan K3 Dengan Perilaku Tidak Aman Pada Karyawan Departemen Produksi di PT X Jakarta.}

Pelatihan menjadi komponen utama dari semua program keselamatan kerja. Pelatihan dilakukan dengan tujuan untuk meningkatkan pemahaman terhadap resiko dan bahaya di tempat kerja. Dengan meningkatnya kesadaran pekerja terhadap resiko, maka pekerja diharapkan dapat 
terhindar dari perilaku tidak aman yang menyebabkan kecelakaan kerja.

Berdasarkan hasil analisis univariat karyawan di departemen produksi sebanyak $55,6 \%$ karyawan divisi produksi pernah mengikuti pelatihan, jumlah ini lebih banyak dibandingkan karyawan yang tidak pernah mengikuti pelatihan yaitu sebanyak $44,4 \%$. Dari hasil analisis bivariat menggunakan $c h i$ square test didapat nilai $\mathrm{P}$ value $=0,04$ maka adapat disimpulkan bahwa ada hubungan signifikan antara pelatihan dengan perilaku tidak aman pada karyawan departemen produksi di PT X Jakarta Tahun 2021.

Dari penelitian Salim dapat menyimpulkan bahwa ada hubungan yang kuat antara pelatihan dengan perlikau tidak aman pekerja yang sesuai dengan hasil penelitian ini. Program pelatihan K3 harus lebih tersusun lebih baik lagi dalam pengaturan agenda pelatihan dan lebih ditingkatkan agar para pekerja lebih memiliki kesadaran untuk berperilaku aman dalam bekerja. Selain itu juga pekerja dapat meningkatkan keterampilan pekerja yang nantinya dapat meningkatkan produktivitas. $^{12,13}$

Berdasarkan hasil kuesioner penelitian diketahui masih terdapat karyawan yang belum mengikuti seluruh program pelatihan sebanyak $44,4 \%$ hal ini dikarenakan adanya jadwal pelatihan yang tidak dapat diikuti oleh karyawan yang sedang shift 2 atau shift 3 . Pihak departemen K3 dan kepala bagian produksi harus menjadwal dengan baik terutama untuk karyawan yang belum pernah mengikuti pelatihan K3 harus di buatkan jadwal kerja shift 1 sehingga dapat mengikuti pelatihan yang sedang berlangsung.

Berdasarkan hasil kuesioner melalui uji chi square menyatakan bahwa karyawan yang tidak pernah pelatihan berperilaku tidak aman $75 \%$ lebih banyak dibandingkan karyawan yang mendapat pelatihan berperilku tidak aman sebanyak 40\%. Berdasarkan hasil kuesioner penelitian pelatihan yang paling banyak diikuti oleh karyawan adalah pelatihan Damkar dan evakuasi kondisi emergensi, pelatihan mengenai alat-alat produksi yang diperbarui, pelatihan tentang 5R (Ringkas, Rapi, Resik, Rawat dan Rajin), pelatihan penggunaan APD yang benar dan sesuai, pelatihan terkait bahaya dan cara pengendaliannya di produksi, pelatihan $\mathrm{K} 3$ terkait cara angkatangkut beban, Pelatihan tentang MSDS (Material Safety Data Sheet) terkait bahaya dan risiko serta penanganan bahan kimia. Berdasarkan hasil penelitian diketahui karyawan yang pernah mengikuti pelatihan lebih sedikit melakukan perilaku tidak aman karena adanya pemahaman materi yang diterima oleh karyawan setelah menjalankan pelatihan K3 yang diadakan perusahaan sedangkan karyawan yang belum mengikuti pelatihan akan cenderung melakukan perilaku tidak aman lebih tinggi seperti tidak menggunakan APD dengan benar, tidak memperhatikan kapasitas mesin yang digunakan karena mengejar target dan tidak menerapkan 5R dalam proses kerja ${ }^{14,15}$.

Menurut pihak depatemen K3 program pelatihan terkait $\mathrm{K} 3$ juga masih belum maksimal dikarenakan pihak perusahaan beralasan sedang memiliki banyak pengeluaran, sehingga terkadang trainer yang didatangkan dari luar kurang kompoten dalam pemnyampaian materi. Sebaiknya pihak perusahaan memperdayakan SDM (Sumber Daya Manusia) yang ada, dengan memberikan fasilitas pelatihan seminar K3 yang bersertifikasi sehingga ilmu yang didapat dapat disampaikan di dalam perusahaan dengan lebih mendalam dan lebih tepat sasaran karena telah menguasai setiap proses produksi sehingga dapat mengetahui sumber bahaya ada.

\section{Hubungan Antara Pengawasan Dengan Perilaku Tidak Aman Pada Karyawan Departemen Produksi di PT X Jakarta.}

Pengawasan merupakan kegiatan yang sangat berpengaruh dalam setiap proses yang bertujuan agar setiap pekerjaan dapat terlaksana sesuai dengan agenda yang telah ditetapkan sehingga diperoleh hasil yang dikehendaki.

Hasil analisis univariat pada karyawan di departemen produksi diketahui pengawasan kategori baik lebih besar yaitu $60 \%$ dibandingkan pengawasan dalam kategori tidak baik sebesar $40 \%$. Nilai $\mathrm{P}$ value $=0,03$ dari hasil analisa bivariat menggunakan uji chi square dapat diartikan adanya hubungan antara pengawasan dengan perilaku tidak aman pada karyawan departemen produksi di PT X Jakarta Tahun 2021. 
Menurut Sangaji et al menyimpulkan bahwa adanya hubungan yang kuat antara pengawasan dengan perilaku tidak aman ${ }^{7}$. Sesuai dengan penelitian Pangestu \& Kusumaningtyar menyimpulkan bahwa ada hubungan yang kuat antara pengawasan dengan perilaku aman para pekerja. ${ }^{11} \mathrm{Hal}$ ini sesuai dengan hasil penelitian yang diperoleh bahwa ada hubungan yang signifikan antara pengawasan dengan perilaku tidak aman di lingkungan kerja.

Berdasarkan hasil kuesioner peneliti responden menjawab paling tinggi terkait pernyataan perlunya diadakan pengawasan ditempat kerja. Berdasarkan hasil wawancara alasan responden menjawab pernyataan tersebut karena menurut karyawan di departemen produksi hal tersebut dilakukan mengontrol dan memonitor seluruh kegiatan pada proses produksi sehingga ada yang bertanggung jawab terhadap pekerjaan yang mereka lakukan Berdasarkan hasil kuesioner melalui uji chi square menyatakan proporsi tertinggi pengawasan yang tidak baik yaitu perilaku tidak aman sebesar $77,8 \%$. Dan pengawasan baik berperilaku tidak aman sebesar 59,3\%. Menurut peneliti adanya pengawasan yang baik seperti pengawasan rutin serta inspeksi secara berkala bisa menurunkan jumlah kasus perilaku tidak aman yang dilakukan oleh karyawan pada divisi produksi. Hal ini tidak terlepas dari dukungan supervisor dan rekan kerja sebagai pelaksana pengawasan. Dukungan supervisor yaitu seperti memberikan reward kepada karyawan yang telah patuh dalam bekerja secara aman dan bentuk dukungan rekan kerja yaitu saling mengingatkan pentingnya penggunaan APD dalam kelancaran proses bekerja. Semakin baik peran supervisor sebagai pengawas langsung dalam sebuah departemen dalam melakukan inspeksi K3 maka akan sangat mempengaruhi jumlah kasus perilaku tidak aman pekerja di tempat tersebut. ${ }^{16}$ Supervisor diharapkan dapat mampu menumbuhkan rasa tanggung jawab yang pada akhirnya akan membentuk perilaku kerja yang aman (Safe Behavior) untuk pekerja itu sendiri.

\section{KESIMPULAN}

Berdasarkan hasil penelitian proporsi tertinggi adalah perilaku tidak aman yaitu sebesar 55,6\%. Pada variabel umur proporsi tertinggi karyawan produksi dengan kategori muda $80 \%$. Pada variabel pendidikan proporsi tertinggi adalah pendidikan dasar yaitu 82,2. Pada variabel pengetahuan proporsi tertinggi kategori pengetahuan tinggi $66,7 \%$. Pada variabel pelatihan proporsi tertinggi adalah kategori pelatihan pernah pelatihan $55,6 \%$ dan pada variabel pengawasan proporsi tertinggi adalah kategori pengawasan baik sebesar $60,0 \%$.

Berdasarkan hasil penelitian diperoleh bahwa tidak ada hubungan antara umur dan pengetahuan terhadap perilaku tidak aman pada karyawan divisi produksi PT X Jakarta Tahun 2021. Serta terdapat hubungan antara pendidikan, pengawasan dan pelatihan terhadap perilaku tidak aman pada karyawan divisi produksi di PT X Jakarta Tahun 2021.

\section{DAFTAR PUSTAKA}

1. Bangun W. Manajemen Sumber Daya Manusia. International J, editor. Jakarta: Erlangga; 2012. 4 p.

2. Mutia A, Ekawati, Wahyuni I. Analisis Faktor-Faktor Yang Berhubungan Dengan Perilaku Tidak Aman Pada Pekerja Di Departemen Produksi Pt. X. J Kesehat Masy. 2017;5(5):1-9.

3. Saragih F, Lubis H, Tarigan L. Faktorfaktor yang berhubungan dengan tindakan tidak aman pada pekerja lapangan PT. Telkom cabang Sidikalang Kabupaten Dairi Tahun 2014. Kesehat Masyarakat[ejournal]. 2014;

4. Tri. Angka Kecelakaan Kerja Cenderung Meningkat, BPJS Ketenagakerjaan Bayar Santunan Rp1,2 Triliun [Internet]. BPJS Ketenagakerjaan. 2019. Available from: https://www.bpjsketenagakerjaan.go.id/be rita/23322/Angka-Kecelakaan-Kerja-

Cender. Diakses 4 April 2020

5. Sholihin S, Atjo WM. Hubungan Persepsi K3 Karyawan Dengan Perilaku Tidak Aman di Bagian produksi unit IV PT . Semen Tonasa Tahun 2013 Relations Of Perception K3 Employee With Unsafe Behavior In The Production Unit IV Pt .Semen Tonasa Year 2013. Bagian K3 Fakultas Kesehatan Ma. 2013;1-4.

6. Sudrajat A. Hubungan antara Pengetahuan, Sikap, dan Motivasi dengan Perilaku Tidak Aman pada Pekerja Di PT. Muroco Playwood Jember. [Internet]. Universitas Jember; 2017. Available from: 
https://repository.unej.ac.id/bitstream/handle/123 456789/82591/Agung 122110101200_.pdf? sequence $=1 \&$ isAllo wed $=\mathrm{y}$

7. Sangaji J, Jayanti S, Lestantyo D. FaktorFaktor Yang Berhubungan Dengan Perilaku Tidak Aman Pekerja Bagian Lambung Galangan Kapal Pt X. J Kesehat Masy. 2018;6(5):563-71.

8. Pratama A. Hubungan karakteristik pekerja dengan unsafe action pada tenaga kerja bongkar muat di PT. Terminal Petikemas Surabaya. Indones J Occup Saf Heal. 2015;4(1):64-73.

9. Listyandini R. Analisis Faktor Yang Berhubungan Dengan Perilaku Tidak Aman Pada Pekerja Kontraktor Di PT. X. Universitas Airlangga; 2013.

10. Ulumuddin, Kusumaningtyar D, Alia KMC. Relation Man Factors with Work Accident in Injection Phylon Unit at PT. $X$. In: Int Conf Heal [Internet] [Internet]. Indonesia: Scitepress.org; 2020. p. 294303. Available from: https://www.scitepress.org/PublicationsD etail.aspx?ID $=17 \mathrm{wVHeDNGOM}=\& \mathrm{t}=1$

11. Pangestu G, Kusumaningtyar D. Factors Which Related to Safety Behavior of Ironworkers in Thamrin Nine Phase II Project PT. Total Building Persada TBK 2019. 2020;9:328-37.

12. Salim M. Faktor-Faktor Yang Berhubungan Dengan Perilaku Tidak Aman Pada Pekerja Kontruksi Pt Indopora Proyek East 8 Cibubur Jakarta Timur. J Ilmu Kesehat. 2019;10(2):17380.

13. Bella S, Nurjanah. Perilaku Tidak Aman (Unsafe Behaviour) Pada Pekerja Di Unit Material PT Sango Ceramics Indonesia Semarang. J Kesehat (isiKes. 2015;14(2):109-14.

14. Risqa PY, Syamsulhuda, Cahyo K. Beberapa Faktor Yang Berpengaruh Terhadap Perilaku Kerja Aman (Safety Behavior) Petani Tembakau Di Kabupaten Temanggung. J Kesehat Masy. 2019;7(1):545-53.

15. Setiarsih Y, Setyaningsih Y, Widjasena B. Hubungan Karakteristik Pekerja, Promosi K3, Dan Ketersediaan Alat Pelindung
Diri (Apd) Dengan Perilaku Tidak Aman Pada Pekerja Mechanical Maintenance. J Kesehat Masy. 2017;5(5):424-33.

16. Shiddiq S, Wahyu A, Muis M. Hubungan Persepsi K3 Karyawan dengan Perilaku Tidak Aman di Bagian Produksi Unit IV PT. Media Kesehat Masy Indones. 2016;10(2):110-6. 